\title{
ADOLESCENTS’ MENTAL HEALTH COMPONENT IN UKRAINE
}

\section{Щудро С. А. Психічний складник здоров'я підлітків в Україні}

Проблема охорони психічного здоров'я в усьому світі останнім часом $є$ дуже актуальною. Психічне здоров'я дитини $є$ важливим складником загального здоров'я, воно забезпечує рівновагу індивідууму з навколишнім середовищем і суспільством.

Мета роботи полягала в проведенні теоретичного аналізу досліджень психічного складника здоров'я підлітків для визначення шляхів реформування системи загальної середньої освіти й збереження здоров'я майбутнього покоління.

Дослідження психологічних особливостей юнаків і дівчат 14 - 16 років показало, що серед учнів, які навчались в інноваційних закладах, визначалися такі кластери: характерологічний, тривожнісний, акцентуйовано-темпераментно-логічний, невротичний, нервово-психічний, координаційний, навчально-значущий, пізнавально-значущий, зоровомоторний, зорово-сенсорний.

Оцінка психогігієнічних показників в учнів свідчить, що серед підлітків виокремлюється значний відсоток високих за значенням показників нейротизму, ситуаційної та особистісної тривожності, а також таких типів акцентуацій особистості, як гіпертимний, екзальтований, циклотимічний, що суттєво впливає на формування внутрішньої картини хвороби в підлітків.

Охорона здоров'я дітей і підлітків - одне 3 найголовніших завдань, оскільки воно визначає здоров'я, благополуччя та прогрес нації. Кризові явища та низький соціальноекономічний рівень суспільства, несприятливі екологічні чинники, бездуховність, бідність, незбалансоване харчування, навчальне навантаження, недостатня рухлива активність, стрес, насильство, відсутність змістовного дозвілля - причини негативних тенденцій у стані здоров'я дітей і підлітків, що потребує розробки нових підходів до формування та поліпшення їхнього здоров'я.

Теорія профілактичної медицини розглядає систему “підлітки-школа-сім'ясередовище" як відкриту динамічну систему, яка досягає оптимуму свого функціонування лише за умов тісної взаємодії кожної з ланок системи: структури та функцій організму, особистісних факторів, активності та участі, факторів навколишнього середовища. Пріоритетну позицію серед факторів життєдіяльності підлітків займають школа та сім'я. Різні аспекти шкільної та сімейної медицини досліджені багатьма науковцями, проте проблема психічного складника здоров'я дітей і підлітків i ii вплив на соматичний i соціальний складники ще далека від остаточного розв'язання.

Ключові слова: підлітки, здоров'я, психіка, школа, сім'я, середовище

\section{Щудро С. А. Психическая составляющая здоровья подростков в Украине}

Проблема охраны психического здоровья подростков во всем мире является очень актуальной, психическое здоровье ребенка - важной составляющей здоровья. Оно обеспечивает равновесие индивидуума, общества и окружающей среды.

Цель работы состояла в проведении теоретического анализа исследований психической составляющей здоровья подростков с целью определения путей реформирования системы общего среднего образования и сохранения здоровья будущего поколения.

Исследования психологических особенностей юношей и девушек 14 - 16 лет показало, что среди учащихся, обучающихся в инновационных учреждениях, определялись такие кластеры: характерологический, тревожный, акцентуировано-темпераментно-логичный, невротический, нервно-психический, координационный, обучающе-значимый, познавательно-значимый, зрительно-моторный, зрительно-сенсорный.

Оценка психогигиенических показателей у учащихся свидетельствует, что среди подростков отмечается значительный процент высоких по значению показателей 
нейротизма, ситуационной и личностной тревожности, а также таких типов акцентуаций характера, как гипертимный, экзальтированный, циклотимический, что существенно влияет на формирование внутренней картины болезни подростков.

Охрана здоровья детей и подростков - одна из основных задач, поскольку она определяет здоровье, благополучие и прогресс нации. Кризисные явления и низкий социально-экономический уровень общества, неблагоприятные экологические факторы, бездуховность, бедность, несбалансированное питание, обучающие нагрузки, недостаточная физическая активность, стресс, насилие, отсутствие содержательного досуга - причины негативных тенденций в состоянии здоровья детей и подростков, что требует разработки новых подходов к улучшению их здоровья.

Теория профилактической медицины рассматривает систему «подростки-школа-семьясреда» как открытую динамическую систему, которая достигает оптимума своего функционирования только при условии тесного взаимодействия каждой из составляющих системы: структуры и функций организма, активности и участия, факторов окружающей среды. Приоритетную позицию среди факторов жизнедеятельности подростков занимает школа и семья. Разные аспекты школьной и семейной медицины изучены множеством исследователей, но проблема психической составляющей здоровья детей и подростков и ее влияние на соматическую и социальную составляющие еще далека от окончательного решения.

Ключевые слова: подростки, здоровье, психика, школа, семья, среда

\section{Shchudro S. A. Adolescents' mental health component in Ukraine}

The problem of mental health care has been very urgent around the world lately. Child's mental health is an important component of overall health; it provides a balance of the individual with the environment and society.

The purpose of the work is to conduct a theoretical analysis of the studies of the mental component of adolescents' mental health in order to identify ways of reforming the secondary school education system and preserving the health of the future generation.

The study of psychological traits of 14-16 year-old boys and girls showed that such clusters as characterological, psychological, anxiety, accentuated-temperamental-logical, neurotic, neuropsychic, coordination, educational-meaningful, cognitive-significant, visual-motor, visual-sensory were identified among students who studied in innovative institutions.

Assessment of psycho-hygienic indicators in students shows that there is a significant percentage of high points of neuroticism, situational and personality anxiety, as well as types of personality accentuation such as hypertensive, exalted, cyclothymic. That influences on internal aspect of the adolescents' disease.

Protecting children's and adolescents' health is one of the most important governmental tasks because it defines the health, well-being and progress of the nation. Crises and low socio-economic level of society, adverse environmental factors, spirituality, poverty, unbalanced nutrition, training load, insufficient mobility, stress, violence, lack of meaningful leisure are causes of negative trends for children's health. It needs developing new approaches to shaping and improving their health.

Preventive medicine theory views the "adolescent-school-family-environment" system as an open dynamic system that achieves the optimum of its functioning only under the close interaction of each one of the system link: structure and functions of the organism, personal factors, activity, participation and environmental factors. School and family have a high priority in the life cycle of adolescents. Many aspects of school and family medicine have been investigated by many scholars, but the problem of the mental component of the health of children and adolescents and its impact on somatic and social components is far from being finally researched.

Key words: adolescents, health, psyche, school, family, environment

Formulation of the problem. The problem of mental health care has been very urgent around the world lately $[11 ; 30]$. Child's mental health is an important component of overall health, it provides a balance of the individual with the environment and society [4; $8 ; 15 ; 25]$. 
According to the World Health Organization, about two-thirds of premature deaths and onethird of the overall burden of illness in adults are related to living conditions and behavioral characteristics created in childhood by family and society [cit. for 12]. The formation of positive life views in adolescence should also be aimed at psychological protection, overcoming social maladaptation, increasing the level of personality stress [11; 30]. The rapid process of changing the socio-economic and environmental conditions of life of children and adolescents requires a high level of physical, physiological, mental and moral adaptation. The negative impact of social, biological factors on adolescents' personality leads to violations of adaptation processes in the organizm, causes acute and chronic non-communicable diseases and disorders of the mental state [24].

The functional state of mental health is reflected in the mental capacity of the students and is a direct consequence of the learning activity and the emotional status associated with it. An important place is occupied by inability to cope with the workload, lack of contact with teachers, school staff, motivation to study among all the reasons that cause problems in students' psycho-emotional sphere of both innovative and traditional educational institutions. Any unwanted changes in the psyche of children and adolescents inevitably lead to a mood deterioration and negative emotional manifestations. Psychologists and psychiatrists attribute the positive emotional state and emotional reactions to the most important criteria for a safe mental health [17; 33].

Analysis of scientific research. In the hygienic evaluation of pedagogical innovations, a number of researchers found that the number of cases of severe fatigue by the end of the school day in adolescents engaged in fundamentally new technologies of education, compared with students of traditional mainstream schools, is $40,0-50,0 \%$ of cases, against 25,0-38,0 \%. Determining the number of neurotic reactions in students, depending on the volume of educational load, it was found that this rate reached 78,8-85,0 \% in teenagers who studied by pedagogical innovation, against 60,0 $\%$ in students of secondary schools. It has been shown that the increase of influence of psychogenic factors and the increase of their intensity in the course of training contribute not only to the increase of the frequency of functional disorders at the age of 15-17 years, but also to the acceleration of the rate of formation of chronic diseases [7; 20]. Other researchers, as a result of a comprehensive assessment of the health of older students, showed that the number of adolescents who are quite healthy (2,3 \% vs. 10,1 \%) is significantly lower than in secondary schools (2,3 \% vs. 10,1\%) have functional impairments also less (24,3 \% vs. 38,8 \%). In high schools and lyceums, the percentage of students with chronic diseases is higher (73,4 \% vs. 51,1\%) [20].

Analysis of psycho-physiological and behavioral features of the senior high school students showed that senior high school students are often sleepwalking in the form of sensitive sleep, nightmares or they need to take sleeping pills, their mood swings, and they get aggressive, they feel bad and have headaches. The problem is the high consumption of alcohol (25,2 and 18,4\%) and smoking (18,9 and 18,2 \%) in girls compared to boys [18].

A study of the mental health of adolescents under stress indicates that $78,4 \%$ of adolescents experience changes in personality disorders and $16,2 \%$ of them have mild depression of situational genesis. They revealed an increase in the level of personal anxiety to $54,5 \pm 4,7$ points against the background of reducing the level of stress and social adaptation to $208 \pm 27$ points [12].

One of the most common psychoneurological disorders is attention deficit hyperactivity disorder [3; 23]. Its prevalence in school students reaches $16.6 \%$, in boys and girls, it occurs in 21,4 $\%$ and 11,8 \% respectively, its prevalence in rural students reaches 23,0 \%, while this syndrome occurs in every tenth urban student. All children with attention deficit hyperactivity disorder with normal intelligence had difficulty in learning (dyslexia, dysgraphia, dysarthrography), which was reflected in studying success. The disharmony of morpho-functional status in children with this syndrome is associated with a deficiency in body weight, whereas children without it are thought to be overweight. The morbidity analysis revealed that in diseases of the nervous system, deviations from the musculoskeletal system, diseases of the endocrine system and multiple dental caries are common for children with attention deficit hyperactivity disorder [23].

A number of studies suggest that the emotional state of students of all ages (five, nine and eleven-year students) is directly dependent on the factors of influence of the learning environment. The beginning of the school year is marked by students' better psycho-emotional status, which 
tends to worsen towards the end of their studies. The psychological tone index, which reflects the emotional state of the team, is higher in five-year students than in nine- and eleven-year students. Emotional ups and downs do not always coincide with physiologically determined periods of productivity and workability due to the effects of learning factors. These effects include the irrationally drawn up schedule of lessons, extra lessons in the afternoons, and the presence of a large number of test work in one day. All these aspects cause adverse reactions of the unstable psyche of children and adolescents.

The purpose of the work is to conduct a theoretical analysis of the studies of the mental component of adolescents' mental health in order to identify ways of reforming the secondary school education system and preserving the health of the future generation.

Presenting basic material and research results. The decrease in the functionality of adolescents' central nervous system is manifested in the accelerated increase in the number of mistakes while doing corrective tests after difficult subjects (from 17,3 $\pm 1,6$ to 23,1 \pm 1,9 \% in different classes) compared with moderate growth after the average difficulty subjects $(8,4 \pm 0,5$ to $12,3 \pm 0,8 \%$ in different school years) and slight increase or decrease in mistakes after easy subjects (increase from 4,2 $\pm 0,3$ to $5,8 \pm 0,5 \%$ or mistake reduction from 10,6 $\pm 1,1$ to 15,4 $\pm 1,5$ $\%$ in different school years) [22; 29].

The results of proofreading studies before and after the lessons at different study organization showed that the productivity of college students' mental work did not change significantly from the beginning to the end of the school day (8,93 $\pm 1,49$ and 9,49 $\pm 1,62 \%$ respectively) and practically was not different from the results obtained in secondary education institutions and innovative institutions with traditional training organization. However, the rates of complex indicators of mental workability, which characterize the ratio of favorable and unfavorable types of students' workability curves, unlike secondary education institutions, in college acquire rates below the critical ones (1,0: 0,99 before lessons and 1,0: 0,76 after lessons). That indicated the advantage of unfavorable types of students' workability [28].

The use of computers and radio terminals leads to a deterioration of their health status in children, characterized by decreased visual function, immune system and psycho-emotional sphere, stress syndrome, aggressiveness and irritability, abusiveness and suspicion [32]. Indicators of healthy fatigue (accommodation volume (17,39 \% right eye and 17,02 \% left eye), critical fusion of light flashes $(11,27 \%$ right eye and 8,81 \% left eye), dynamic tremor $(8,13 \%)$, proofreading rates: total errors (12,52 \%), job accuracy (5,31 \%), and productivity (9,52 \%) [ 29]. When looking at gender differences on the impact of visual load, it was found that thermometry is the most sensitive (43,99 \%); heart rate (24,63 \%); vegetative index of Kerdo (19,77\%); proofreading: total number of signs viewed (17,95 \%) and number of errors (18,59\%), productivity (19,41\%); the Miznikov index $(8,07 \%)$; systolic blood pressure $(5,30 \%)$ are the most sensitive to the effects of visual load on computer games of various types [28].

The organization of studying according to the term-module principle does not significantly affect the self-esteem of students' psycho-emotional state. At the same time, the level of students' neuroticism in different forms of studying organization differs in favour of the module-term construction of the educational process. The analysis of the assessment results of students' psychoemotional status by levels of personal and reactive anxiety indicates that the level of signs of children's neuroticism by the indicator of reactive anxiety decreased while organizing the educational process on a term-module basis [31].

Destabilization processes in society, psycho-emotional abuse in families and educational institutions are reflected in the mental development of children and adolescents. In order to reduce their incidence of mental and behavioral disorders in Ukraine, the system of training and advanced training of medical and pedagogical staff is being improved, new methods and approaches aimed at preventing and recognizing pathology and timely treatment are being introduced [29].

A number of studies have identified the factors that determine the formation of deviant behavior in adolescents: education in hypoopia, single parent, low level of material support, conflict in families, high proportion of cerebral-organic factors, neuropathy in early childhood, the presence of neurosis, difficulties in school adaptation, communicative deviance and school curriculum overload. The greatest share in adolescents of school age had aggression (69,4\%), character 
reaction in the form of protest (34,5\%), negativism (34,5\%), opposition (30,0\%), queerliness (24,4 $\%)$ and grouping reaction $(24,4 \%)$.

There are behavior deviations (20,8 \%), which cause substance abuse, smoking (18,7 \%) and alcohol (18,1 \%), immoral behavior (12,6 \%), overvalued psychological hobbies (12,2 \%), communicative deviations (10,3\%), on the second place. There is computer addiction (5,6\%), autism (5,4 \%), gambling (5,4 \%), autoarchy (3,2 \%), eating disorders in the form of overeating (2,4 $\%)$ and starvation (1,5\%), kleptomania $(1,1 \%)$, religious fanaticism $(0,9 \%)$, anesthesia $(0,9 \%)$ on thee third place. There is a low control of aggression in $43,5 \%$ of students, aggression as a trait in $31,8 \%$, and aggression as a condition in 14,8 \% [31].

A number of researchers have identified a likely higher number of individuals with low dependency on the collective, high self-efficacy, self-esteem, and oriented towards the acquisition of their own life experience (factor Q2) in 15-17 year-old adolescents [20, 27]. Adolescents with depressive neurotic disorders have a high proportion of the level of neuroticism on the scale of neurotic depression (92,5 \%), anxiety (30,0\%), obsessive-phobic disorders (36,3\%), and autonomic disorders (36,3\%). The maximum level on the asthenia scale is identified while the level on the hysterical response scale is reduced in almost all adolescents with depressive neurotic disorders. Adolescents with depressive neurotic disorders have a certain constellation of elevations in the severity of the neurotic component: neurotic depression (-34,5 points), anxiety (-22,7 points) [16].

There were significant differences in the factors C, D, G, L found among the factors characterizing the emotional-volitional features. There was a greater level of emotional instability, low tolerance for frustration, high sensitivity, tendency to change mood, irritability, irritability increased fatigue, tendency to neurotic syndromes, hypochondria (factor -C) in a considerable number of students. They are characterized by a lower level of excitability, impulsiveness characterized by prudence, silence, care and prudence. The tendency for complications and pessimistic perception of reality (factor -D) is also students' characteristic. The adolescents are characterized by a higher level of social norms perception, conscious conduction of the rules, purposefulness in achieving goals, accuracy, responsibility, business orientation (factor -G). They were characterized by a higher level of firmness, courage, self-confidence, prudence, realistic judgment, practicality and insensitivity to others (factor-L) [6, 20].

Factors A, E, H, J, which characterize the communicative properties and features of interpersonal relationships, have significant differences in adolescents. Most students had a clear cyclothymia, individuals with a dominance for these features are more open and kind, they are inherent in naturalness and immediacy. However, this factor may indicate the inconsistency of a person and tendency to affectitis (factor + A). They have a higher level of obedience, people with a preference for this trait are more timid. They tend to be respectful, but their submissiveness can be completely passive (factor -E). There is a higher level of social courage, activity, readiness to deal with unfamiliar circumstances and people. They are more risk-averse, significantly loose and unbuttoned ( $+\mathrm{H}$ factor). They are characterized by a higher level of conformism, collectivism, while the individual is more dependent on the group, social thought, prefers collective types of work and decision-making, focuses on social approval, they often lack initiative in decision-making (factor-J) [6; 20].

The use of statistical methods for the study of psychological characteristics of boys and girls of 14-16 years showed that such clusters as character (the leading indicators of character traits), anxious (indicators of situational anxiety and characteristics of neuro-psychological tension), accentuated-temperamental-logical (degree of extraversion of personality and accentuation of personality traits), neurotic (indicators of neuroticism of personality), neuro-psychic and (indicators of neuro-mental state), coordination (coordination of organism abilities), educational-significant (influence of educational activity on the functional state of adolescents), cognitive-significant (influence of cognitive activity on the functional state of adolescents), visual-motor (characteristics of visual-motor reaction), visual-sensory (characteristics of visual-sensory reaction) ones were identified in students who studied in innovative institutions [19].

Assessment of psycho-hygienic indicators in students shows that there is a significant percentage of high points of neuroticism, situational and personality anxiety, as well as types of 
personality accentuation such as hypertensive, exalted, cyclothymic in adolescents. The level of neuroticism ranges from $13,68 \pm 0,92$ to $15,88 \pm 0,77$ points in girls; from $11,25 \pm 0,81$ to $13,20 \pm$ 0,93 points is in boys, but 50,0 \% of 12-year-old adolescents in the distribution structure have an increased level of neuroticism, and half of them are of very high level; there is the increased level $(40,0 \%)$ in 13-14 year-old teenagers, and there is only $25 \%$ in 15 year-old students, it tends to decrease with age. An increased level of neuroticism is found only in 30,0 \% of 12-year-old girls, gradually increasing and it is already detected in 53,0 \% of 15 year-old students. The strongest correlation was found between indicators of neuroticism and personal anxiety $(r=+0,75)$, a clear correlation was found between high rates for screening cardiac, pulmonological, endocrine and psychological disorders in schoolchildren's health and accentuation by excitatory, dysthymic and exalted types $(r=+0,70)$. High rates of neuroticism and personal anxiety correlated with signs of pathology of the urogenital, cardiovascular, endocrine, respiratory systems and with indicators of psychological disorders $(\mathrm{r}=+0,50-0,79)$ [2; 26].

A pathopsychological symptom complex, which means certain emotional and affective disorders, memory impairment with sufficient indirect memory performance, changes in active attention in the form of narrowing its volume, and difficulty in concentration, is formed in children and adolescents with extreme mental and behavioral disorders. Self-esteem allows making certain representations of patients regarding their health, mental abilities, character, mood, happiness and confidence [14].

Clinical and psychological examination of 14-16 year-old adolescents with brain disfunction revealed such types of personality formation in boys as disordered, aggressive, labile, sexually fixed, hysteroid, apathetic, schizoid, paranoid ones[9]. Low self-control and indiscipline (-Q3), dishonesty $(-G)$, persistence for persistence $(+E)$, increased excitability or excessive reactivity to minor stimuli with negligible stimuli and minor stimuli $(+D)$, low intellectual performance $(-B)$. The overactivity of these boys was combined with impulsiveness and risk aversion $(+F)$ as well as cruelty and overconfidence $(-I)$.

The qualities that determine the personality of such adolescents are irresponsibility, high risk aversion, disregard for social norms and low self-control, perseverance and desire for independence, impatience, reactivity, excitability in response to insignificant provocative stimuli in combination with motor anxiety, abtraction and self-confidence, which create difficulties in social adaptation, require a clear conduction of rules. Their "problematic personal zones" are in the communicative and social spheres, their "problematic factors" are socially communicative ones, they are intensified by impatience, reactivity, self-confidence and insufficient formation of cognitive functions, which can generally lead to a decrease in social adaptation $[1 ; 9 ; 13]$.

The boys with an aggressive personality formation style were free to communicate, dominated among peers $(+\mathrm{A})$, and were not only independent and striving for leadership, but also aggressive $(+\mathrm{E})$. The willing of power, self-confidence, stubbornness, aggressiveness and a tendency to selfesteem lead to confrontation between classmates and adults. These teenagers were conflicted, aggressive, more cautious, always blamed others for conflicts, tried to authoritarianly deal with relationships. At the same time, they were characterized by excessive optimism and reassessment of their capabilities, carelessness, neglect of danger and risk aversion $(+F)$, realistic approach to situations, practicalism and cruelty $(-\mathrm{I})$.

The boys of this group differed not only by their high excitability, expressive impulsiveness and excessive reactivity to minor provocative factors, but also by overconfidence $(+D)$, lack of social control over their behavior (-Q3). It was found that factors B, D and E are similar to each other, and the factors F, G, Q3 differ significantly comparing the data obtained from adolescents with disordered and aggressive types of personality formation disorders. Indicators of impulsiveness, carelessness, risk aversion, low self-control, poor understanding of social norms, responsibility and irresponsibility significantly prevailed and were hypertrophied in impaired adolescents in comparison with the aggressive adolescents who were deprived of adolescence, and the expressiveness of their maladaptive manifestations. At the same time, an increase in A indicates relatively greater social fitness of aggressive adolescents [1; 9; 13].

The most characteristic and distinctive feature of adolescents with a labile type of personality disorder was a change in mood. The "problem zones" are the violations of the emotional-volitional 
sphere-factors C, I, O, Q3, Q4. Significant deviations from the norm of indicators of the neurotic triad $(\mathrm{O}, \mathrm{Q} 3, \mathrm{Q} 4)$ in the boys of this group indicate a high level of their emotional tension and frustration. Comparative analysis of psychological characteristics of adolescents with labile type of personality formation disorder and adolescents with personality disorder by aggressive and disordered types found diametrically opposite tendencies as in the block of emotional-volitional qualities (high points - by factors I, O, Q4 and low ones - by factor C), and on the block of communicative qualities (low points by factors $\mathrm{H}$ and $\mathrm{E}$ ), and normative - by factors $\mathrm{F}$ and $\mathrm{A}[1 ; 9$; $10 ; 13]$.

Adolescents with sexual-fixed type of personality formation disorder were characterized by increased company $(+A)$, independence in dealing with peers $(+E)$, impulse excess $(+$ Q4), low intellectual functions $(+B)$, efficiency $(+\mathrm{H})$, variability of interests $(-\mathrm{C})$, reduced control over their emotions (-Q3), unscrupulousness $(-G)$, self-confidence $(-I)$, and confidence $(-O)$. The "problematic personal zones" that defined the disorders of adolescent personality development in this group were deviations by the factors $+\mathrm{E},+\mathrm{H},+\mathrm{Q} 4,-\mathrm{G},-\mathrm{C},-\mathrm{B},-\mathrm{Q}$. They are characterized as emotional-volitional disorders ( + Q4, $-\mathrm{G},-\mathrm{C},-\mathrm{Q} 3)$ and communicative properties $(+\mathrm{E},+\mathrm{H})[1$; 9; 10; 13].

The boys with dyslexic personality disorders were "personally close" to aggressive and disordered teenagers. They were identified by perseverance and independence $(+E)$, irresponsibility $(-\mathrm{G})$ and adventurism $(+\mathrm{H})$, low self-control $(-\mathrm{Q} 3)$, and on the other hand, they were labile, and they were united by the similarity of such personal qualities as frustration $(+$ Q4) and mood variability $(-\mathrm{C})[9 ; 10]$.

The clear deviations from the normative indicators in hysteroid adolescents by the factors $+\mathrm{I}$, $+\mathrm{O},-\mathrm{D}$ and + Q4 were "problematic personal zones" that determined the "pathological" personal development of the teenagers. The increase in the block of emotional and volitional factors determines the exacerbation of already existing hysteroid traits, and the establishment of deviations in the block of factors of the "neurotic triad" (+ O, + Q4, -Q3) indicates a high level of emotional tension [9; 10].

Adolescents with apathetic personality-development disorders were characterized by confined behaviour $(-A)$, reduced intelligence $(-B)$, fatigue and tendency to hypochondria $(-C)$, irresponsibility $(-\mathrm{G})$, restraint in communication $(-\mathrm{H})$, disorganization $(-\mathrm{Q} 3)$, external inviolability (-Q4). The complex of "problematic personal zones", which deform the adequate personal development of the adoloscents, are factors $-\mathrm{A},-\mathrm{B},-\mathrm{C},-\mathrm{G},-\mathrm{H},-\mathrm{Q} 3,-\mathrm{Q} 4$. They revealed negative deviations in most of the factors of the emotional-volitional block and the block of neurotic triad, which is a reflection of emotional-volitional disorders, which are combined with immaturity of the motivational-need sphere and disturbance of communicative qualities [9; 10].

A characteristic feature of adolescents with schizoid personality disorder is sufficient intelligence $(+B)$ and reasonableness $(-F)$, despondency $(+A)$ and restraint $(-H)$, indiscretion $(-G)$ and indiscipline $(-\mathrm{Q} 3)$, courageous independence $(-\mathrm{I})$ and inviolability $(-\mathrm{Q} 4)$. The boys of this group are characterized by a decline in points on the blocks of factors of communicative characteristics and interpersonal interaction that reflect their ability to communicate with adults and peers. Their distinctive personal characteristics were seclusion, alienation, distrust in communication, weakness of intuition in communication [9; 10].

Adolescents with paranoid type of personality formation disorder were characterized by seclusion $(+A)$, instability of emotions $(-C)$, irresponsibility $(-G)$, practicality $(-I)$, inability to control their behavior against social norms $(-Q 3)$, aggression $(+E)$, low mood $(+O)$, clear frustration (+ Q4). These boys were charecterized by seclusion, despondency, rigidity of thinking, display of distrust of others, and especially of peers (-A), which determined their absence of friends. As a rule, they showed indifference to others and preferred to be alone, with a lack of respect for their responsibilities and poor understanding of social rules $(-G)$, low self-esteem $(-C)$, anxiety, depression, pessimistic fears, constant anxiety $(+\mathrm{O})$, stubbornness, aggressiveness, conflict, tendency to consider your mindset as law for others $(+\mathrm{E})$.

Boys' personality traits such as internal tension, frustration, irritability, tension and excess emotions, which were not found in the process of activity (+ Q4) were particularly exacerbated and hypertrophied. The personality differences of adolescents with schizoid and paranoid disorders of 
personality formation appeared to be similar by the qualitative parameters of a number of factors. The teenagers of both groups are characterized by despondency, rigidity, irresponsibility, cruelty, prudence, inability to control their behavior in relation to social norms and rules. However, indicators of factor Q4, which characterize non-touchability (-Q4) and frustration (+ Q4) had diametrically opposite values in adolescents with schizoid and paranoid types of personality disorder. Only schizoid adulescents were characterized by such qualities as embarrassment and pessimism in the perception of reality $(-\mathrm{F})[9 ; 10]$.

The revealed features of the internal health picture of adolescents with somatic diseases related to the substantive personal components of the internal health picture structure, which revealed the adolescents' perceptions of their health through the definition of mental, psychoemotional, physical and other individual-personal properties. If the group of personal components of the inner picture of the health of healthy adolescents includes such components as motivationalneed, value, self-esteem, emotional, behavioral, bodily, cognitive, volitional and control component; an additional component of belief was included in adolescents with somatic diseases, and it included adolescents' hopes for recovery, rapid overcoming of illness [21].

Psychological features of adolescents, which are exacerbated due to the decline of the family institution, the emergence of nuclear and subnuclear family, increasing information, accelerating the pace of life lead to the disorientation of young people, the need to make their own choices, to make decisions that adversely affects health in some cases. Adolescents need creating clinics that address their needs, which are predetermined by the specificity of adolescence, and provide medical, psychological and social assistance through understanding youth problems [5].

Conclusions. Human health is the highest social and individual value, which significantly influences the processes and results of economic, social and cultural development of the country, determines the state of national security and it is the most important criterion for the welfare of the society.

Protecting children's and adolescents' health is one of the most important governmental tasks because it defines the health, well-being and progress of the nation. Crises and low socio-economic level of society, adverse environmental factors, spirituality, poverty, unbalanced nutrition, training load, insufficient mobility, stress, violence, lack of meaningful leisure are causes of negative trends for children's health. It needs developing new approaches to shaping and improving their health.

Preventive medicine theory views the "adolescent-school-family-environment" system as an open dynamic system that achieves the optimum of its functioning only under the close interaction of each one of the system link: structure and functions of the organism, personal factors, activity, participation and environmental factors. School and family have a high priority in the life cycle of adolescents. Many aspects of school and family medicine have been investigated by many scholars, but the problem of the mental component of the health of children and adolescents and its impact on somatic and social components is far from being finally researched.

\section{Література}

1. Барденштейн Л. М., Можгинский Ю. Б. Патологическая агрессия подростков. М. : Медпрактика, 2005. 260 с.

2. Безрукава Н. Ю. Використання показників психофізіологічних функцій та особливостей особистості як інтегральних критеріїв гігієнічної оцінки функціонального стану організму підлітків. Гігієна населених місць. 2007. № 50. С. 317-320

3. Брязгунов И. П., Семенович И. П. Дефицит внимания с гиперреактивностью у детей М. : Медпрактика, 2002. 128 с.

4. Венар Ч., Кериг П. Психопатология развития детского и подросткового возраста. СПб. : Пройм-Еврознак, 2004. 384 с.

5. Вирабова А. Р., Кучма В. Р., Степанова М. И. Личностно ориентированное обучение детей и подростков: гигиенические проблемы и пути решения. М. : Пробел-2000, 2006. 436 с. 6. Коробчанський В. О., Васильченко I. О., Витріщак С. В. Гігієнічна оцінка факторів ризику, як критеріїв якості життя підлітків різних соціальних груп. Гігієна населених місць. 2007. № 49. С. 332-336. 
7. Степанова М. И., Куинджи Н. Н., Ильин А. Г. Гигиенические проблемы реформирования школьного образования. Гигиена и санитария. 2000. № 1. С. 40-44.

8. Гозак С. В., Сєрих Л. В., Станкевич Т. В. Стан здоров'я дітей з тяжкими порушеннями мовлення - вихованців шкіл-інтернатів. Гігієна населених місць. 2009. № 54. С. 327-331.

9. Даценко И. Б. Личностные особенности подростков с мозговой дисфункцией. Мед. психология. 2008. № 2. С. 18-23.

10. Даценко И. Б. Нейродинамическая семиотика эмоционально-поведенческих и личностных расстройств у подростков с мозговой дисфункцией. Междунар. мед. журн. 2010. № 1. С. 15-22.

11. Исаев Д. Н. Психопатология детского возраста. СПб. : СпецЛит., 2007. 463 с.

12. Клименко В. І., Василькова Ю. В. Охорона психічного здоров'я підліткового населення в умовах стресу. Охорна здоров’я України. 2009. № 1. С. 99-100.

13. Гурьева В. А., Дмитриева Т. Б., Макушкин Е. В. Клиническая и судебная подростковая психиатрия; под ред. В. А. Гурьевой. М. : МИА, 2007. 488 с.

14. Козидубова В. М. Результаты изучения психологических особенностей в возрастном аспекте. Мед. психология. 2008. № 2. С. 35-38.

15. Коробчанський В. О. Гігієнічна психодіагностик до нозологічних станів у підлітковому та юнацькому віці. Х. : Контраст, 2005. 192 с.

16. Проскурина Г. Ю., Михайлова Е. А., Мителев Д.А., Матковская Т. Н. К проблеме депрессий у школьников подросткового возраста. Моніторинг здоров'я школярів: міжсекторальна взаємодія лікарів, педагогів, психологів : матеріали наук.-практ. конф. 3 міжнар. участю 21-22 жовт. 2009 р. Харків: ДУ “ІОЗДП АМНУ”, 2009. С. 91-93.

17. Лебединець Н. В., Полька Н. С. Динаміка здоров'я школярів інноваційного учбового закладу семестрово-цикло-блочного системою навчання. Гігієна населених місць. 2007. № 50. С. 337-343.

18. Максименко Ю. А. Психофізіологічні особливості учнів старших класів. Гігієна населених місць. 2009. № 54. С. 287-290.

19. Малачкова Н. В., Сергета І. В. Використання кластерного аналізу в гігієнічних дослідженнях, що спрямовані на встановлення закономірностей впливу чинників умов перебування на стан зорової сенсорної системи підлітків 14 - 16 років. Гігієна населених місць. 2007. № 50. С. 314-317.

20. Попов О. І., Лупаренко С. Є., Гончаров А. В. Орієнтація вальдорфських засобів розвитку пізнавальної активності у дітей на цілісну психічну структуру особистості як фактор зміцнення здоров’я. Гігієна населених місць. 2009. № 54. С. 335-339.

21. Кирилова О. О., Бєляєва О. Є., Кукурудза Г. В., Цилюрик С. М. Особливості внутрішньої картини здоров'я підлітків із соматичними захворюваннями. Моніторинг здоров'я школярів: міжсекторальна взаємодія лікарів, педагогів, психологів : матеріали наук.-практ. конф. 3 міжнар. участю 21-22 жовт. 2009 р. Харків: ДУ “ІОЗДП АМНУ”, 2009. С. 52-54.

22. Пересыпкина Т. В., Даниленко Г. Н. Особенности динамики умственной работоспособности школьников в зависимости от пола и стадии полового созревания. Моніторинг здоров'я школярів: міжсекторальна взаємодія лікарів, педагогів, психологів : матеріали наук.-практ. конф. 3 міжнар. участю 21-22 жовт. 2009 р. Харків: ДУ “ІОЗДП АМНУ", 2009. С. 81-85.

23. Платонова А. Г. Выявление синдрома дефицита внимания с гиперактивностью у современных школьников. Гігієна населених місць. - 2007. № 50. С. 355-358.

24. Психология подростка. Под ред. А. А. Реана. СПб. : Прайм-Еврознак, 2006. 480 с.

25. Семенович А. В. Нейропсихологическая диагностика и корррекция в детском воздасте. М. : Академия, 2002. 232 с.

26. Сергета I. В., Безрукава Н. Ю. Інтегральний підхід до гігієнічної оцінки та моніторингу функціонального стану дітей та підлітків. Вісник морфології. 2006. № 12. С. 273-275.

27. Сергета I. В., Боровський Б. Р. Особливості розвитку психофізіологічних функцій в умовах використання програми психогігієнічної корекції функціонального стану організму, особливостей особистості і професійної придатності учнів і студентів, що здобувають 
спеціальності у сфері залізничного транспорту. Гігієна населених місць. 2009. № 54. С. 290295.

28. Сисоєнко Н. В. Гігєнічна оцінка семестрово-модульної організації навчально-виховного процесу. Гігієна населених місць. 2007. № 50. С. 351-355.

29. Сисоєнко Н. В., Сєрих Л. В., Целінко Т. В. Гігєнічна оцінка розкладів уроків в загальноосвітніх навчальних закладах 3 використанням нової рангової шкали оцінки важкості навчальних предметів. Гігієна населених місць. 2007. № 49. С. 388-392.

30. Скугаревская Е. И. Клиническая психиатрия. Детский возраст. Минск : Высш. школа, 2006. 463 c.

31. Михайлова Е. А., Проскуріна Т. Ю., Мітельов Д. А. Структура девіантної поведінки у підлітків та фактори, що їі детермінують. Моніторинг здоров'я школярів: міжсекторальна взаємодія лікарів, педагогів, психологів : матеріали наук.-практ. конф. 3 міжнар. участю 2122 жовт. 2009 р. Харків: ДУ “ІОЗДП АМНУ”, 2009. С. 74-75.

32. Чорна В. В. Комп’ютер і комп’ютерні ігри. Гігієна населених місць. 2008. № 52. С. 338342.

33. Школа и психическое здоровье учащихся / под ред.

Медицина, 1988. 271 с.

\section{References:}

1. Bardenshteyn L. M., Mozhhynskyy Yu.B. (2005). Patolohycheskaya ahressyya podrostkov. M. : Medpraktyka, $260 \mathrm{~s}$.

2. Bezrukava N.Yu. (2007). Vykorystannya pokaznykiv psykhofiziolohichnykh funktsiy ta osoblyvostey osobystosti yak intehral'nykh kryteriyiv hihiyenichnoyi otsinky funktsional'noho stanu orhanizmu pidlitkiv. Hihiyena naselenykh mists. № 50. S. 317-320

3. Bryazhunov Y.P. (2002). Defytsyt vnymanyya s hyperreaktyvnostyu u detey. M. : Medpraktyka. $128 \mathrm{~s}$.

4. Venar C.H., Keryh P. (2004). Psykhopatolohyya razvytyya detskoho y podrostkovoho vozrasta. SpB. : Proym-Evroznak. 384 s.

5. Vyrabova A.R., Kuchma V.R., Stepanova M.Y. (2006) Lychnostno oryentyrovannoe obuchenye detey y podrostkov: hyhyenycheskye problemy y puty reshenyya. M. : Probel-2000. 436 s.

6. Korobchanskyy V.O., Vasylchenko I.O., Vytrishchak S.V. [ta in.] (2007). Hihiyenichna otsinka faktoriv ryzyku, yak kryteriyiv yakosti zhyttya pidlitkiv riznykh sotsialnykh hrup. Hihiyena naselenykh mists. № 49. S. 332-336.

7. Stepanova M.I., Kuindzhi N.N., Il'in A.G. [i dr.] (2000). Gigiyenicheskiye problemy reformirovaniya shkolnogo obrazovaniya. Gigiyena i sanitariya. № 1. S. 40-44.

8. Gozak S.V., Serikh L.V., Stankevich T.V. (2009). Stan zdorovya dítey z tyazhkimi porushennyami movlennya - vikhovantsív shkíl-ínternatív. Gígíena naselenikh místs’. № 54. S. 327-331.

9. Datsenko I.B. (2008). Lichnostnyye osobennosti podrostkov s mozgovoy disfunktsiyey. Med. psikhologiya. № 2. S. 18-23.

10. Datsenko I.B. (2010). Neyrodinamicheskaya semiotika emotsional'no-povedencheskikh i lichnostnykh rasstroystv u podrostkov s mozgovoy disfunktsiyey. Mezhdunar. med. zhurn. № 1. S. 15-22.

11. Isayev D. N. (2007). Psikhopatologiya detskogo vozrasta. SPb. : SpetsLit. 463 s.

12. Klimenko V.Í., Vasilkova Yu.V. (2009). Okhorona psikhíchnogo zdorov’ya pídlítkovogo naselennya v umovakh stresu. Okhorna zdorovya Ukraini. № 1. S. 99-100.

13. Guryeva V.A., Dmitriyeva T.B., Makushkin Ye.V.i dr. (2007). Klinicheskaya i sudebnaya podrostkovaya psikhiatriya. M. : MIA. $488 \mathrm{~s}$.

14. Kozidubova V.M. (2008). Rezultaty izucheniya psikhologicheskikh osobennostey v vozrastnom aspekte. Med. psikhologiya. № 2. S. 35-38.

15. Korobchanskyy V.O. (2005). Hihiyenichna psykhodiahnostyk do nozolohichnykh staniv u pidlitkovomu ta yunats'komu vitsi. - Kh. : Kontrast. $192 \mathrm{~s}$.

16. Proskuryna H.Yu., Mykhaylova E.A., Mytelev D.A., Matkovskaya T.N. (2009). K probleme depressyy u shkolnykov podrostkovoho vozrasta. Monitorynh zdorovya shkolyariv: mizhsektoral'na 
vzayemodiya likariv, pedahohiv, psykholohiv : materialy nauk.-prakt. konf. z mizhnar. uchastyu 2122 zhovt. 2009 r. Kharkiv: DU “IOZDP AMNU”. -S. 91-93.

17. Lebedynets N.V., Polka N.S. (2007). Dynamika zdorovya shkolyariv innovatsiynoho uchbovoho zakladu semestrovo-tsyklo-blochnoho systemoyu navchannya. Hihiyena naselenykh mists. № 50. S. 337-343.

18. Maksymenko Yu. A. (2009). Psykhofiziolohichni osoblyvosti uchniv starshykh klasiv. Hihiyena naselenykh mists. № 54. S. 287-290.

19. Malachkova N.V., Serheta I.V. (2007). Vykorystannya klasternoho analizu v hihiyenichnykh doslidzhennyakh, shcho spryamovani na vstanovlennya zakonomirnostey vplyvu chynnykiv umov perebuvannya na stan zorovoyi sensornoyi systemy pidlitkiv $14-16$ rokiv. Hihiyena naselenykh mists. № 50. S. 314-317.

20. Popov O.I., Luparenko S.Ye., Honcharovi A.V. [ta in.] (2009). Oriyentatsiya valdorfskykh zasobiv rozvytku piznavalnoyi aktyvnosti u ditey na tsilisnu psykhichnu strukturu osobystosti yak faktor zmitsnennya zdorovya. Hihiyena naselenykh mists. № 54. S. 335-339.

21. Kyrylova O.O., Byelyayeva O.Ye., Kukurudza H.V., Tsylyuryk S.M. (2009). Osoblyvosti vnutrishnoyi kartyny zdorovya pidlitkiv iz somatychnymy zakhvoryuvannyamy. Monitorynh zdorovya shkolyariv: mizhsektoralna vzayemodiya likariv, pedahohiv, psykholohiv : materialy nauk.-prakt. konf. z mizhnar. uchastyu 21-22 zhovt. 2009 r. Kharkiv: DU “IOZDP AMNU”. S. 5254.

22. Peresypkyna T.V., Danylenko H.N. (2009). Osobennosty dynamyky umstvennoy rabotosposobnosty shkol'nykov v zavysymosty ot pola y stadyy polovoho sozrevanyya. Monitorynh zdorovya shkolyariv: mizhsektoralna vzayemodiya likariv, pedahohiv, psykholohiv : materialy nauk.-prakt. konf. z mizhnar. uchastyu 21-22 zhovt. 2009 r. Kharkiv: DU “IOZDP AMNU”. S. 8185.

23. Platonova A.H. (2007). Vyyavlenye syndroma defytsyta vnymanyya s hyperaktyvnost'yu u sovremennykh shkolnykov. Hihiyena naselenykh mists. № 50. S. 355-358.

24. Reana A.A. (2006). Psykholohyya podrostka. SpB. : Praym-Evroznak. 480 s.

25. Semenovych A.V. (2002). Neyropsykholohycheskaya dyahnostyka y korrrektsyya v det•skom vozdaste . M. : Akademyya. $232 \mathrm{~s}$.

26. Serheta I.V., Bezrukava N.Yu. (2006). Intehralnyy pidkhid do hihiyenichnoyi otsinky ta monitorynhu funktsional'noho stanu ditey ta pidlitkiv. Visnyk morfolohiyi. № 12. S. 273-275.

27. Serheta I. V., Borovskyy B.R. (2009). Osoblyvosti rozvytku psykhofiziolohichnykh funktsiy v umovakh vykorystannya prohramy psykhohihiyenichnoyi korektsiyi funktsionalnoho stanu orhanizmu, osoblyvostey osobystosti i profesiynoyi prydatnosti uchniv i studentiv, shcho zdobuvayut spetsial'nosti u sferi zaliznychnoho transportu. Hihiyena naselenykh mists. № 54. S. 290-295.

28. Sysoyenko N.V. (2007). Hihyenichna otsinka semestrovo-modulnoyi orhanizatsiyi navchalnovykhovnoho protsesu. Hihiyena naselenykh mists. № 50. S. 351-355.

29. Sysoyenko N.V., Syerykh L.V., Tselinko T.V. (2007). Hihyenichna otsinka rozkladiv urokiv v zahalnoosvitnikh navchalnykh zakladakh z vykorystannyam novoyi ranhovoyi shkaly otsinky vazhkosti navchalnykh predmetiv. Hihiyena naselenykh mists. 2007. № 49. S. 388-392.

30. Skuharevskaya E.Y. (2006). Klynycheskaya psykhyatryya. Detskyy vozrast. Mynsk : Vyssh. shkola. $463 \mathrm{~s}$.

31. Mykhaylova E.A., Proskurina T.Yu., Mitelov D.A. [ta in.] (2009). Struktura deviantnoyi povedinky u pidlitkiv ta faktory, shcho yiyi determinuyut. Monitorynh zdorovya shkolyariv: mizhsektoralna vzayemodiya likariv, pedahohiv, psykholohiv : materialy nauk.-prakt. konf. z mizhnar. uchastyu 21-22 zhovt. 2009 r. Kharkiv: DU “IOZDP AMNU”. S. 74-75.

32. Chorna V.V. (2008). Kompyuter i komp"yuterni ihry. Hihiyena naselenykh mists. № 52. S. 338-342.

33. Hrombakha S.M. (1988). Shkola y psykhycheskoe zdorove uchashchykhsya. M. : Medytsyna. $271 \mathrm{~s}$. 